\title{
IbM GURU CERDAS GEOGEBRA
}

\author{
Sukmawarti $^{(1)}$,Hidayat ${ }^{2)}$, Firmansyah $^{3)}$,Abdul Mujib ${ }^{4)}$ \\ Universitas Muslim Nusantara Al Washliyah \\ Jl. Garu 2 No. 93 Medan \\ e-mail: bundasukma.umn@gmail.com
}

\begin{abstract}
ABSTRAK
Tujuan program pengabdian ini adalah untuk membantu guru mendesain pembelajaran matematika dengan menggunakan software Geogebra. Metode pelaksanaan yang digunakan adalah pelatihan disain pembelajaran matematika berbantuan software Geogebra. Kegiatan yang dilakukan melalui 4 tahap, yaitu: tutorial, workshop, simulasi (drill and practice), dan games instruction. Sebagai mitra dalam kegiatan pengabdian kepada masyarakat ini adalah SMP Negeri 5 Tebingtinggi yang berada di Desa Teluk Karang Kecamatan Bajenis Kotamadya Tebingtinggi.Target khusus yang dicapai adalah guru matematika SMP Negeri 5 Tebingtinggi mampu mendisain pembelajaran matematika dengan bantuan sotfware geogebra. Luaran yang dihasilkan berupa produk disain pembelajaran matematika dalam bentuk lembar aktivitas matematika berbantuan Geogebra version 3.0.
\end{abstract}

Katakunci: Disain Pembelajaran Matematika, Software Geogebra

\begin{abstract}
The purpose of this community service program is to help teachers designing mathematics learning using Geogebra software. The implementation method used is mathematics learning design training assisted with Geogebra software. Activities are carried out through four stages, namely: tutorials, workshops, simulation (drill and practice), and games instructions.As a partner in this community service program is SMP Negeri 5 Tebing Tinggi. Specific target achieved is mathematics teachers of Tebing Tinggi at SMP Negeri 5 Tebing Tinggi capable of designing mathematics learning assisted with Geogebra software. The output is in the form of mathematics learning design products in mathematics activity sheet assisted with Geogebra version 3.0
\end{abstract}

Keyword: Mathematics Learning Design, Geogebra Software

\section{PENDAHULUAN}

Teknologi informasi (TI) banyak berperan dalam bidang pendidikan. Globalisasi telah memicu kecenderungan pergeseran dalam dunia pendidikan dari pendidikan tatap muka yang konvensional ke arah pendidikan yang lebih terbuka. Teknologi informasi dapat dimanfaatkan dalam pembelajaran sebagai teknologi utama

maupun sebagai teknologi pendukung. Sebagai teknologi utama, TI difungsikan sesuai dengan materi pelajaran dan sebagai teknologi interaksi pembelajaran antara guru dan siswa. Sedangkan sebagai teknologi pendukung, TI digunakan sebagai media pembelajaran dan sebagai fasilitas pembelajaran. Gambaran pola pemanfaatan TI dalam pembelajaran diilustrasikan sebagai berikut:

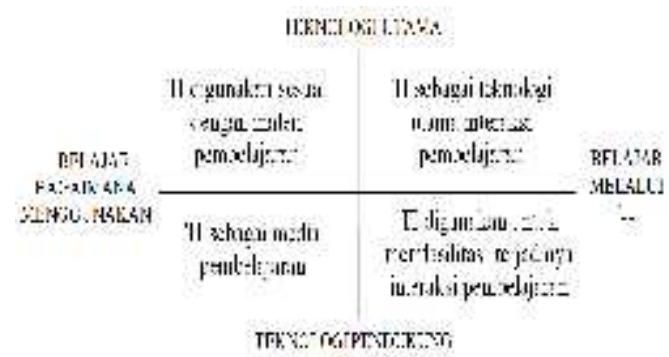

Gambar 1. Pola Pemanfaatan Teknologi dalam Pembelajaran 
Saat sekarang ini tehnologi informasi merupakan hal yang tidak asing bagi sekolah-sekolah, baik yang berada di kota maupun di daerah pinggiran kota. Begitu juga bagi SMP Negeri 5 Tebingtinggi yang berada di pinggiran kota Tebingtinggi, tepatnya di desa Teluk Karang Kecamatan Bajenis. Daya tampung sekolah ini sebanyak 1000 siswa yang tersebar dalam 26 kelas. Sekolah ini termasuk SMP yang relatif baru di kota Tebingtinggi, sehingga guru-gurunya relatif berusia muda yang merupakan usia produktif, yaitu masih memiliki potensi untuk mengikuti perkembangan TI. Jumlah guru matematika yang ada sebanyak 8 orang yang berpendidikan sarjana pendidikan matematika. Sarana yang tersedia disekolah disamping ruang kelas yang standar, ada laboratorium komputer yang memiliki 18 unit PC dengan 1 server dan 5 unit infocus. Tenaga teknisi khusus laboratorium belum ada, namun untuk pengelolaan Laboratorium Komputer ditugaskan seorang guru PPKn sebagai Kepala Laboratorium. Selama ini, Laboratorium dimanfaatkan hanya untuk praktik Microsoft Office bagi siswa. Jaringan Wifi belum ada, namun bagi guru yang memiliki Notebook telah menggunakan Modem untuk melakukan koneksi internet. Pemanfaatan TI oleh guru dalam pembelajaran matematika masih kurang, dimana dari delapan guru matematika hanya satu guru yang memanfaatkan infokus dalam penyajian materi.

Sesuai dengan lokasinya, maka siswa disekolah ini sebagian besar berasal dari daerah pinggiran kota. Intake siswa yang rendah merupakan salah satu faktor yang menentukan KKM Matematika di sekolah tersebut rendah. Menurut informasi dari guru matematika, umumnya kemampuan matematika siswa masih rendah, salah satu penyebabnya adalah minat belajar matematika yang rendah. Tetapi untuk mata pelajatan Teknologi Informasi dan Komunikasi (TIK) minat mereka cukup tinggi. Salah satu penyebabnya adalah dikarenakan pembelajaran TIK yang telah memanfaatkan media Komputer.

Terkait dengan permasalahan IPTEK, SMP Negeri 5 Tebingtinggi memiliki beberapa masalah, yaitu: (1) Tidak ada teknisi khusus bidang TIK di sekolah; (2) Pelatihan TIK yang dikuti guru matematika tidak berkaitan dengan disain pembelajaran matematika; (3) Guru tidak memiliki software pembelajaran matematika; dan (4) Guru tidak mahir dalam memanfaatkan software-software matematika yang ada di internet.

Sebenarnya tehnologi informasi dapat dengan mudah dimanfaatkan dalam pembelajaran. Penggunaan TI dalam pembelajaran dapat mendukung interaksi antara guru, siswa, dan materi pelajaran. Sebagaimana tuntutan kurikulum 2013 yang berbasis sains dan teknologi, dimana pembelajaran harus dikaitkan dengan teknologi. (Badan PSDMPK-PMP Kemendikbud, 2013). Teknologi dapat dimanfaatkan dalam penyajian materi pelajaran dan dapat juga dimanfaatkan sebagai teknologi interaksi pembelajaran antara guru dan siswa.

Pemanfaatan teknologi dalam pembelajaran matematika dapat menggunakan bantuan softwaresoftware matematika, salah satunya software Geogebra. GeoGebra adalah software open source di bawah GNU (General Public License) dan tersedia gratis di www.geogebra.org. Dengan demikian, file installer dapat didownload secara langsung, atau 
Geogebra dapat di instal langsung dari internet menggunakan GeoGebra WebStart. Karena software ini berbasis Java, maka software ini independen dan berjalan pada setiap sistem operasi. Selain itu, GeoGebra adalah multibahasa tidak hanya di menu, tetapi juga dalam perintah, serta diterjemahkan oleh relawan dari seluruh dunia ke dalam lebih dari 35 bahasa (GeoGebra $3.0)$. (Hohenwarter, 2006)

Namun Pemanfaatan komputer sebagai Computere Basic Instruction (CBI) oleh guru dalam pembelajaran matematika memerlukan rancangan khusus agar sesuai dengan materi pelajaran, prinsip pedagogi, karakteristik siswa, dan juga menarik. Untuk itu perlu dibuat suatu desain pembelajaran berbasis komputer. Hal ini dapat dilakukan bagi guru-guru matematika di SMP Negeri 5 Tebingtinggi, mengingat: (1) Guru mampu mengoperasikan komputer dengan baik; (2) Guru memiliki minat yang tinggi terhadap perkembangan media pembelajaran berbasis TIK; dan (3) Guru cukup potensial untuk dilatih mendisain pembelajaran matematika menggunakan software Geogebra version 3.0.

\section{METODE PELAKSANAAN}

Model pembelajaran berbasis TI sangat mewarnai pengembangan perangkat lunak dalam sistem pembelajaran konstruktivisme. Pembelajaran berbasis TI dengan sofware Geogebra version 3.0 bermanfaat untuk membantu guru dalam mengajar dan membantu siswa dalam belajar.

Untuk melaksanakan program pengabdian ini dilakukan 4 tahap kegiatan, yaitu: tutorial, workshop, simulasi (drill and practice), dan games instruction. Kegiatan yang dilakukan sebagai berikut:

Tabel 1. Tahap Pelaksanaan Kegiatan

\begin{tabular}{|c|c|}
\hline Kegiatan & Deskripsi Kegiatan \\
\hline Tutorial & $\begin{array}{ll}\text { - } & \text { Menjelaskan tentang } \\
\text { mendisain pembelajaran. } \\
\text { - } & \text { Menjelaskan penggunaan } \\
& \text { software Geogebra dalam } \\
\text { pembelajan matematika. }\end{array}$ \\
\hline Workshop & $\begin{array}{l}\text { Pembimbingan dalam membuat } \\
\text { disain pembelajaran berbasis IT } \\
\text { dengan software geogebra } \\
\text { version } 3.0\end{array}$ \\
\hline $\begin{array}{l}\text { Simulasi } \\
\text { (Drill and } \\
\text { Practice) }\end{array}$ & $\begin{array}{l}\text { Peserta mempraktekkan hasil } \\
\text { disain pembelajaran yang } \\
\text { dirancang. }\end{array}$ \\
\hline $\begin{array}{l}\text { Games } \\
\text { Instruction }\end{array}$ & $\begin{array}{l}\text { Pengembangan disain } \\
\text { pembelajarn berbasis TI dengan } \\
\text { menggunakan software } \\
\text { geogebran dalam kelas. }\end{array}$ \\
\hline
\end{tabular}

\section{HASIL DAN PEMBAHASAN}

Pembelajaran matematika yang memanfaatkan TI memungkinkan interaksi siswa dengan siswa dan interaksi siswa dengan guru. Disain pembelajaran berbasis TI yang ditawarkam bisa berbentuk tulisan, suara, warna, gambar, gerak, simulasi, mesin mengajar dan sebagainya. Prinsip yang digunakan ini sejalan dengan prinsip belajar conditioning operan, belajar melalui serangkaian stimulusrespon dan belajar bermakna (Arsyad, 2008).

Pelaksanaan pengabdian masyarakat ini telah dilakukan dalam 4 kegiatan, yaitu tutorial, workshop, Simulasi, dan games instruction. Serangkaian kegiatan yang dilakukan ini memberikan dampak potitif bagi mitra. Deskripsi kegiatan yang telah dilakukan serta hasil dari kegiatan dapat dilihat pada tabel Deskrifsi dan Hasil Kegiatan. 
Tabel 2. Deskripsi dan Hasil Kegiatan

\begin{tabular}{|c|c|}
\hline Deskripsi Kegiatan & Hasil Kegiatan \\
\hline \begin{tabular}{|l} 
Tutorial \\
- Pembukaan \\
- Mensepakati \\
kontrak pelatihan \\
dan jadwal \\
pelatihan \\
- Menjelaskan \\
tentang mendisain \\
pembelajaran. \\
- Menjelaskan \\
penggunaan \\
software Geogebra \\
dalam pembelajan \\
matematika.
\end{tabular} & $\begin{array}{l}\text { - Kesepakatan } \\
\text { Kontrak dan } \\
\text { jadwal pelatihan } \\
\text { - Peserta mendapat } \\
\text { pengetahuan } \\
\text { tentang disain } \\
\text { pembelajaran } \\
\text { - Peserta mendapat } \\
\text { pengetahuan } \\
\text { tentang Software } \\
\text { GeoGebra, }\end{array}$ \\
\hline \begin{tabular}{|l} 
Work-shop \\
- Pembimbingan \\
dalam membuat \\
fiture dengan \\
software geogebra \\
- Pembimbingan \\
membuat disain \\
pembelajaran \\
matematika dengan \\
software geogebra
\end{tabular} & $\begin{array}{l}\text { Peserta mampu } \\
\text { membuat } \\
\text { - konstruksi } \\
\text { Geometri Dasar } \\
\text { - Disain } \\
\text { pembelajaran luas } \\
\text { lingkaran }\end{array}$ \\
\hline $\begin{array}{l}\text { Simulasi } \\
\text { Peserta menerapkan } \\
\text { hasil rancangan disain } \\
\text { pembelajaran luas } \\
\text { lingkaran berbasis } \\
\text { software geogebra } \\
\text { version } 3.0\end{array}$ & $\begin{array}{l}\text { Peserta mampu } \\
\text { menggunakan } \\
\text { software geogebra } \\
\text { version } 3.0 \text { dalam } \\
\text { membelajarkan luas } \\
\text { lingkaran. }\end{array}$ \\
\hline $\begin{array}{l}\text { Games Instruction } \\
\text { Pengembangan disain } \\
\text { pembelajarn berbasis } \\
\text { TI dengan } \\
\text { menggunakan } \\
\text { software geogebran di } \\
\text { dalam kelas. }\end{array}$ & $\begin{array}{l}\text { Peserta } \\
\text { mempraktekkan } \\
\text { pemanfaata software } \\
\text { geogebra version } 3.0 \\
\text { di dalam kelas untuk } \\
\text { konsep luas } \\
\text { lingkaran }\end{array}$ \\
\hline
\end{tabular}

Hasil kegiatan workshop dalam bentuk disain pembelajaran matematika salah satunya desain pembelajaran konsep luas daerah ligkaran.
Adapun Langkah-langkah yang ditempuh untuk mengkonstruksinya sebagai berikut:

1. Buat slider $\boldsymbol{a}$ untuk menentukan banyaknya partisi lingkaran, dan slider $\boldsymbol{R}$ untuk menentukan panjang jari-jari lingkaran.

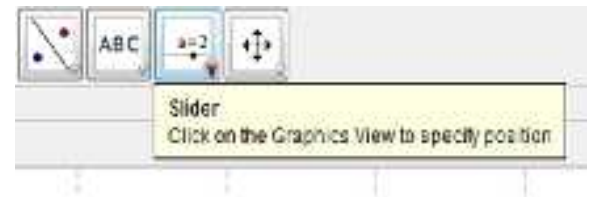

Pada Menu toolbar, Klik tool slider, maka akan muncul jendela slider

seperti pada gambar di bawah. Terdiri dari jenis slider (Bilangan, Sudut, dan Bilangan bulat), nama slider, interval, dan incremen (Penambahan), Slider (Tampilan Slider vertikal atau horisontal), dan Animasi.

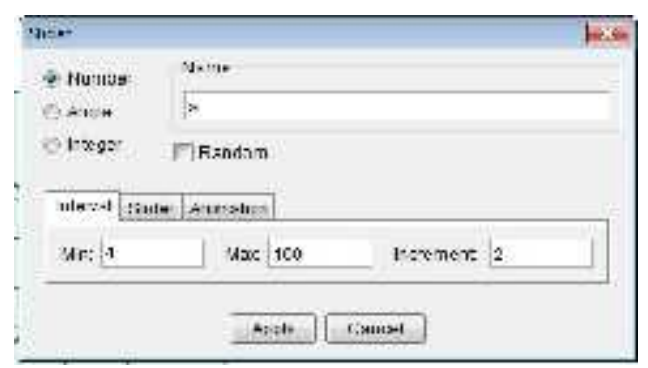

2. Buat lingkaran dengan pusat A dan jari-jari yang sudah ditentukan, yaitu R.

Klik tool Circle with Centre and Radius, klik pada layar grafik, maka akan muncul kotak dialog yang menanyakan panjang jari-jari, ketik $\mathrm{R}$ artinya kita membuat lingkaran dependent dengan pusat A dan jari-jari bergantung pada slider R. Coba geser slider R! (terlebih dahulu aktifkan tool move)

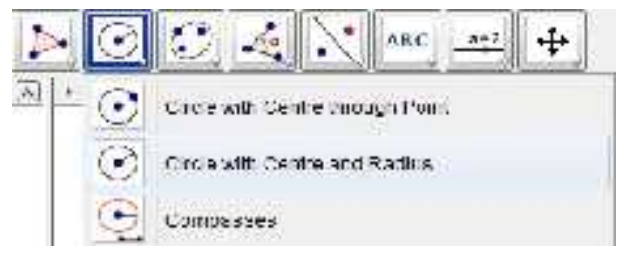


3. Membuat titik B pada lingkaran Klik tool point, kemudian klik pada lingkaran yang berpusat di titik A dan berjari-jari R. Maka kita peroleh titik B yang terletak pada lingkaran. Coba geser titik B! Jika titik B bergerak mengelilingi lingkaran, maka titik B terletak pada lingkaran.

4. Membuat sequensi (rentetan) titik berdasarkan titik B untuk mempartisi lingkaran.

Pada Input Bar ketikkan :

Sequence[Rotate $\left.\left[B, 360^{\circ} / a * i, A\right], i, 1, a\right]$

Kemudian enter.

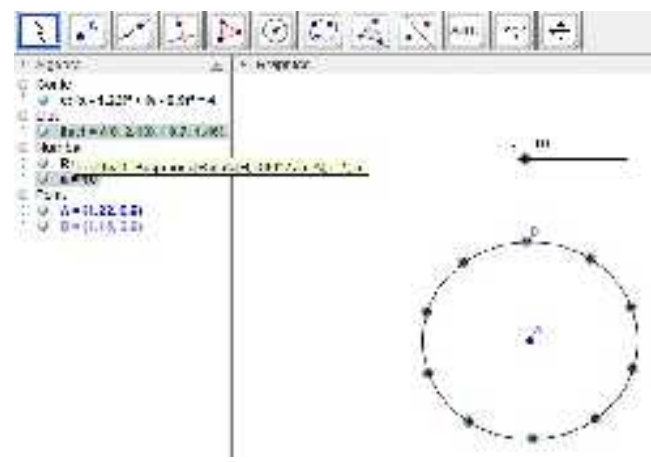

Keterangan:

Rotate[B,360/a*i.A] artinya kita melakukan rotasi titik $\mathrm{B}$ dengan pusat A sebesar $360^{\circ}$ a. Dimana a adalah slider. Jadi besar sudutnya bergantung pada slider a. Variabel $i$ menyatakan besarnya pengali sudut dari 1 sampai dengan a.

5. Membuat partisi lingkaran.

Pada Input bar ketikkan :

Sequence[CircularSector[A, Rotate[B, (i - 1)* $\left.360^{\circ} / \mathrm{a}, \mathrm{A}\right]$, Rotate[B, i* $\left.\left.\left.360^{\circ} / \mathrm{a}, \mathrm{A}\right]\right], \mathrm{i}, 1, \mathrm{a}\right]$

Keterangan:

Sircular sector adalah juring lingkaran. Perintah untuk membuat juring adalah sircularsector[A,B,C) dimana A pusat lingkaran, $\mathrm{B}$ dan $\mathrm{C}$ adalah titik-titik pada lingkaran.
6. Membuat titik bebas $\mathrm{C}$ yang mewakili titik pusat lingkaran A.

Aktifkan tool titik kemudian tentukan sebuah titik $\mathrm{C}$ di luar lingkaran sebelah kanan.
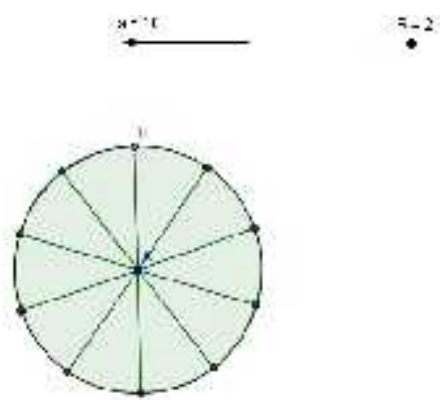

7. Membuat segmen $\mathrm{CD}$ yang panjangnya sama dengan $\mathrm{R}$.

Pada tool line, klik tool segment with fixed lenght, maka akan muncul jendela pajang segment.

ketik R kemudian enter. Posisikan ruas garis $\mathrm{CD}$ vertikal.

8. Membuat titik D' yang merupakan rotasi searah jarum jam dari titik D sebesar $180 \%$ a dengan pusat rotasi titik C. Ketik:

Kotate $\left[D,-\left(180^{\circ}\right) / u_{1} C\right.$

9. Membuat Juring CDD'.

Pada input bar, ketik:

CircularSector $\left[C, D^{\prime}, D\right]$

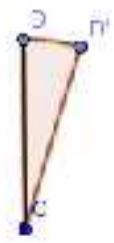

10. Membuat titik C' yang merupakan hasil rotasi titik $\mathrm{C}$ sebesar $360 \%$ dengan pusat rotasi D', Ketik :

Rotate $\left[C, 360^{\circ} / u_{,} D^{\prime}\right]$

11. Membuat Juring D'CC'.

Pada input bar, ketik:

Circular Sector $\left[D^{\prime}, C_{1} C^{\prime}\right]$

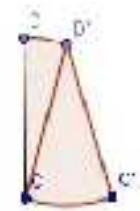

12. Dengan cara yang sama dengan sebelumnya kita buat titik D" yang merupakan hasil rotasi titik D' dengan pusat titik C'. Kemudian buat juring C'D' D'. 
13 Membuat sequensi titik $\mathrm{C}$ dan sequensi titik D.Ketik :

sequence $\left[C+i\left(C^{\prime}-C\right), i_{1}, a / 2\right]$

Sequerce $\left[D^{\prime}+i\left(D^{\prime \prime}-D^{\prime}\right), i_{1} 1,(a-2) / 2\right]$

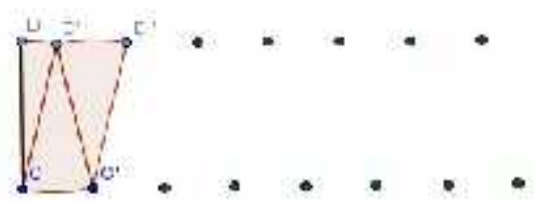

14. Membuat sequensi juring C'D''D'

Ketik:

Sequence[Sector[Translate[Circle [C', D"], i Vector[D', D"]], Translate[D", i Vector[D', D"]], Translate[D', i Vector[D', D"]]], i, $1, \mathrm{a} / 2$ - 2]

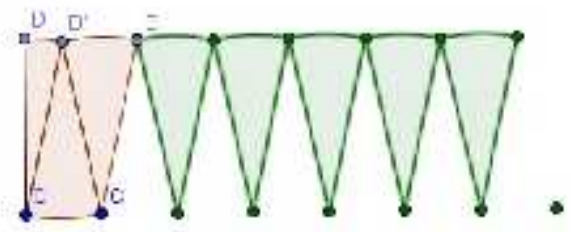

15. Membuat sequensi juring C'D' 'D'

Ketik:

Sequence[Sector[Translate[Circle $\left[D^{\prime}, \quad \mathrm{C}\right], \quad \mathrm{i}$ Vector$\left.\left[\mathrm{C}, \mathrm{C}^{\prime}\right]\right]$, Translate[C, i Vector[C, $\left.\left.\mathrm{C}^{\prime}\right]\right]$, Translate[C', i Vector[C, C']]], i, 1, a / 2 - 1] enter

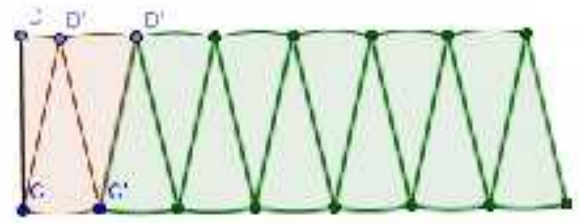

16. Membuat juring yang sebangun CDD' sebagai penutup.

Pertama buat titik E:

Ketik :

Translate[Rotate $\left[D^{\prime}, 18 \mathrm{U}^{*} / \mathrm{a}, \mathrm{C}\right], \mathrm{u} / 2 \mathrm{Vector}\left[\mathrm{C}, \mathrm{C}^{\prime}\right]$

Kemudian buat titik F dan G:

Ketik :

IremsLate[Rotate $\left[D, 180^{*} / u_{1} C\right]$, u $\left./ 2 \operatorname{Vector}\left[C_{i} C^{C}\right]\right]$
Ketik:

Transiat: [Rotate $\left[C, 36 O^{\circ} / b_{2} D^{\prime}\right](z / Z-1)$ Vector $\left[C, C^{\prime}\right]$

Selanjutnya kita buat juring:

CircularSectar $[G, E, F]$

Maka terbentuklah partisi lingkaran yang dinamis.

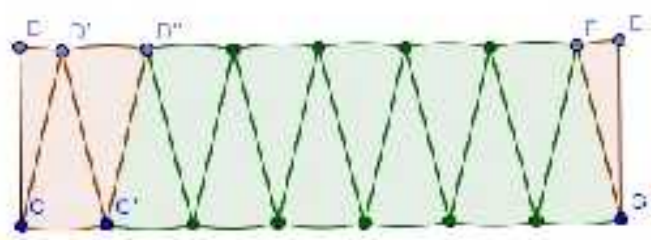

Pemanfaatan

software

GeoGebra dapat membentuk partisi dari sebuah lingkaran menjadi bangun datar segi empat yang bersifat dinamis.

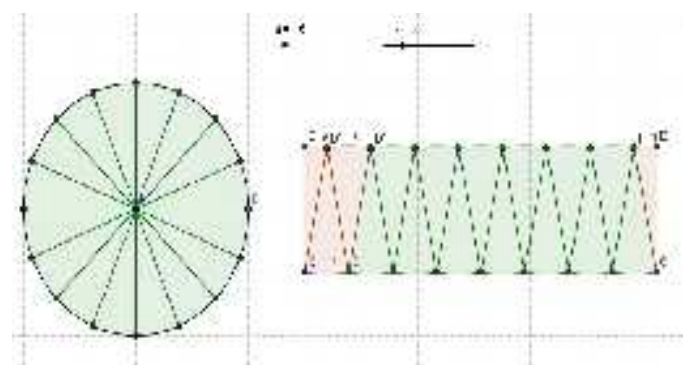

Slider a menyatakan banyaknya partisi lingkaran, dan gambar disamping lingkaran merupakan rekonstruksi partisi lingkaran yang dibangun menjadi sebuah segiempat. Slider $a$ dapat digeser-geser. Jika $a$ semakin besar atau $u>w$, maka semakin banyak partisi lingkaran, sehingga bangun segi empat yang terbentuk semakin mirip dengan persegipanjang.

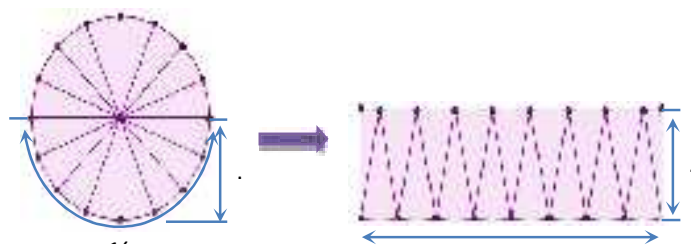

Sehingga untuk menghitung luas lingkaran dapat didekati dengan 
menghitung luas persegipanjang yang terbentuk.

Kegiatan workshop disain pembelajaran ini dapat membantu guru dalam membelajarkan konsep luas lingkaran. Pemanfaatan Software GeoGebra yang bersifat dinamis membantu pemahaman konseptual siswa terhadap materi pelajaran matematika. Siswa dapat belajar melalui pengalaman, dengan pendekatan saintifik.

Hasil dari kegiatan IbM ini memberikan pengetahuan kepada guru-guru matematika SMP Negeri 5 Tebingtinggi. Bentuk pengetahuan tersebut berupa pemanfaatan software dinamis GeoGebra dalam pembelajaran matematika. Hasil yang dicapai ditekankan pada disain lembar kerja bagi siswa sesuai tuntutan kurikulum 2013. Luaran yang dihasilkan adalah perangkat disain pembelajaran matematika berbantuan sftware GeoGebra. Perangkat disain dapat berupa LAS (Lembar Aktivitas Siswa) dan media peraga visual, yang dapat digunakan guru sehingga kegiatan pembelajaran menjadi lebih menarik.

Pelaksanaan kegiatan IbM ini mendapatkan perhatian yang serius dari guru-guru sekolah mitra, karena ternyata kegiatan seperti ini belum pernah diadakan. Kegiatan yang pernah dilakukan merupakan pelatihan kurikulum 2013 hanya sebatas sosialisasi saja, tanpa terapan dan pendampingan. Ketertarikan guru mengikuti kegiatan ini dikarenakan kegiatan ini memberikan peluang bagi guru untuk mengembangkan potensi anak. Selain itu model kegiatan yang dilakukan sangat interaktif dan dapat merespon setiap peserta.

Setelah kegiatan IbM ini dilaksanakan, tim pelaksana optimis bahwa guru-guru peserta pelatihan dapat mengembangkan perangkat disain pembelajaran berbantuan software GeoGebra pada materi matematika lainnya. Indikator keberhasilan program ini adalah $80 \%$ peserta pelatihan mampu membuat perangkat disain pembelajaran matematika berbantuan software GeoGebra. Diharapkan pada masa yang akan datang guru-guru mitra senantiasa berkoordinasi untuk mengembangkan perangkat disain pembelajaran matematika yang lain.

Dengan mengembangkan perangkat disain pembelajaran berbantuan software GeoGebra dapat membuat guru kreatif dan inovatif. Dengan demikian guru-guru yang selama ini cederung menggunakan metode ceramah dengan media seadanya dapat bergeser menerapkan model pembelajaran berbasis teknologi dengan menggunakan software-software pembelajaran yang sesuai.

\section{KESIMPULAN}

Berdasarkan hasil dari pelaksanaan kegiatan pengabdian masyarakat yang telah dilakukan, dapat disimpulkan bahwa kegiatan terlaksana dengan baik dan lancar, serta mendapat respon yang positif dari peserta. Peserta juga mampu menggunakan software Geogebra, dan dapat mendisain perangkat pembelajaran matematika berbasis teknologi dengan menggunakan software GeoGebra. Namun untuk memotivasi guru bereksplorasi dalam mengembangkan disain pembelajaran, perlu diadakan kompetisi mendisain media pembelajaran matematika berbasis Geogebra, selain kegiatan pelatihan dan workshop. 
DAFTAR PUSTAKA

Arsyad, A. (2008). Media

Pembelajaran. Jakarta: Raja Grafindo Persana

Badan PSDMPK-PMP Kemendikbud. (2013). Materi Pelatihan Implementasi Kurikulum 2013. Jakarta: Kemendikbud.

Hohenwarter, M. (2008). GeoGebra. Dynamic mathmatics software. http://www.geogebra.org.

Hohenwarter, M. (2006). Dynamic investigation of functions using GeoGebra. In Proceedings of Dresden

International
Symposium on Technology and its Integration into Mathematics Education, Dresden, Germany. DES-TIME.

Hohenwarter, M. and Preiner, J. (2008). Design guidelines for dynamic mathematics worksheets. Teaching Mathematics and Computer Science.

Ismail, Atik Wintarti. Pembelajaran Matematika Berbasis ICT. Jurnal Pendidikan Matematika dan Sains UNESA, Vol.2, No.16 